\title{
IMPACT OF THE GRADE OF DEGENERATIVE LUMBAR DISEASE ON THE OCCURRENCE OF SPINAL DEFORMITY
}

\author{
IMPACTO DA GRADUAÇÃO DA DOENÇA DEGENERATIVA LOMBAR SOBRE A OCORRÊNCIA \\ DE DEFORMIDADE DA COLUNA VERTEBRAL
}

IMPACTO DE LA GRADUACIÓN DE LA ENFERMEDAD DEGENERATIVA LUMBAR SOBRE LA OCURRENCIA DE DEFORMIDAD DE LA COLUMNA VERTEBRAL

Raphael Batisti, ${ }^{1}$ Carlos Eduardo Algaves Soares de Olivelra, ${ }^{1}$ Raphael de Rezende Pratali ${ }^{1}$

1. Hospital do Servidor Público Estadual de São Paulo, Orthopedics and Traumatology Service, São Paulo, SP, Brazil.

\begin{abstract}
Objetivo: Avaliar o impacto da gravidade da doença degenerativa lombar (DDL) sobre a ocorrência de deformidade vertebral, assim como sobre a escolha do tratamento - conservador ou cirúrgico. Métodos: Trata-se de uma análise retrospectiva de um banco de dados prospectivo. Cento e trinta pacientes com dor lombar e/ou dor irradiada para o membro inferior foram incluídos no estudo e graduados por uma escala de DDL que considera achados radiográficos da coluna total (panorâmica). A taxa de ocorrência de deformidade da coluna vertebral no adulto (DCVA) foi comparada entre os graus da escala da DDL pelo teste de Qui-quadrado. A escolha do tipo de tratamento, conservador ou cirúrgico, foi comparada entre os graus de DDL pelo teste exato de Fisher. Resultados: A taxa de ocorrência de DCVA foi zero nos pacientes com grau 0, $24 \%$ nos pacientes com grau I, 35\% nos pacientes com grau II e $44 \%$ nos pacientes com grau III $(P=0,02)$. Os pacientes com grau III tiveram maior probabilidade de ser diagnosticados com DCVA (OR =2,22; $\mathrm{P}<0,05$; IC de 95\% =0,90-5,45) comparados com os dos indivíduos com outros graus. Apenas 7,7\% dos pacientes foram escolhidos para tratamento cirúrgico, sem diferença quanto ao grau da escala de DDL. Conclusões: Houve correlação entre a escala de graduação da DDL e a ocorrência de DCVA, sendo ao menos duas vezes maior a chance dessa ocorrência no grau III comparado com os demais graus. Na imensa minoria dos pacientes, o tratamento escolhido foi o conservador, sem diferença entre os distintos graus de DDL. Nível de evidência III; Análise retrospectiva de banco de dados prospectivo (coorte).
\end{abstract}

Descritores: Espondilose; Coluna Vertebral; Dor Lombar; Classificação; Radiografia.

\section{RESUMO}

Objective: To evaluate the impact of the severity of degenerative lumbar disease (DLD) on the occurrence of spinal deformity, as well as on the choice of treatment, whether conservative or surgical. Methods: This is a retrospective analysis of a prospective database. One hundred and thirty patients with low back pain and/or pain radiating to the lower limbs were included in the study and were graded on a DLD scale that considers total spine (panoramic) X-ray findings. The rates of adult spinal deformity (ASD) for the different degrees of the DLD scale were compared using the Chi-square test. The choice of treatment type, conservative or surgical, was also compared among the degrees of the DLD scale using Fisher's exact test. Results: The ASD rate was zero in grade 0 patients, $24 \%$ in grade I, $35 \%$ in grade II and $44 \%$ in grade III ( $P$ $=0.02$ ). Grade III patients were more likely to be diagnosed with ASD (OR $=2.22 ; P<0.05 ; 95 \% C l=0.90-5.45)$ compared to the other DLD grades. Only 7.7\% of the patients were chosen for surgical treatment and there was no difference by the DLD scale grade. Conclusion: There was correlation between the DLD grading scale and the occurrence of ASD, with at least twice the chance of this diagnosis in DLD scale grade III as compared to the other grades. The treatment of choice was conservative in a very small number of patients analyzed, with no difference between the different grades of the DLD grading scale. Level of Evidence III; Retrospective analysis of prospective database (cohort).

Keywords: Spondylosis; Spine; Low Back Pain; Classification; Radiography.

\section{RESUMEN}

Objetivo: Evaluar el impacto de la gravedad de la enfermedad degenerativa lumbar (EDL) sobre la ocurrencia de la deformidad vertebral, así como sobre la elección del tratamiento - conservador o quirúrgico. Métodos: Se trata de un análisis retrospectivo de un banco de datos prospectivo. Ciento treinta pacientes con dolor lumbar y/o dolor irradiado para los miembros inferiores fueron incluidos en el estudio y graduados por una escala de EDL que considera hallazgos radiográficos de la columna total (panorámica). La tasa de ocurrencia de deformidad de la columna vertebral en el adulto (DCVA) fue comparada entre los grados de la escala de EDL mediante el test de Chi-cuadrado. La elección del tipo de tratamiento, consenador o quirúrgico, también se comparó entre los grados de EDL mediante el test exacto de Fisher. Resultados: La tasa de ocurrencia de DCVA fue cero en los pacientes con grado 0, $24 \%$ en los pacientes con grado I, 35\% en grado II y 44\% en grado III $(P=0,02)$. Los pacientes con grado III tuvieron mayor probabilidad de ser diagnosticados con DCVA (OR =2,22; $P<0,05 ;$ IC de 95\% =0,90-5,45) en comparación con los individuos con otros grados. Sólo 7,7\% de los pacientes fueron escogidos para tratamiento quirúrgico, sin diferencia sobre el grado de la escala EDL. Conclusiones: Hubo correlación entre la escala de graduación de EDL y la ocurrencia de DCVA, siendo al menos dos veces mayor la posibilidad de esa ocurrencia en el grado III en comparación con los demás grados. En la inmensa minoría de pacientes, el tratamiento escogido fue el conservador, sin diferencia entre los diferentes grados de EDL. Nivel de evidencia III; Análisis retrospectivo de banco de datos prospectivo (cohorte).

Descriptores: Espondilosis; Columna Vertebral; Dolor de la Región Lumbar; Clasificación; Radiografía. 


\section{INTRODUCTION}

The use of total spine radiography in the evaluation of patients with chronic low back pain has become increasingly popular because this modality allows the observation of both radiographic changes in the lumbar segment of the spine and spinal alignment in the coronal and sagittal planes, as well as the measurement of spinopelvic parameters. ${ }^{1}$

The association between changes in spinopelvic parameters and symptomology, including pain and functional disability, is well established as demonstrated in several studies. ${ }^{2-4}$ This correlation was the basis for the development of the SRS-Schwab classification system for adult spinal deformity (ASD). ${ }^{5}$ However, low back pain and consequent functional disability may have several other causes including spondylosis or spondyloarthrosis (disc, facet joint, and vertebral body degeneration), degenerative spinal deformities, vertebral instability (including spondylolisthesis), and central or foraminal canal stenosis with spinal cord or nerve root compression. ${ }^{6}$

Although magnetic resonance continues to be considered the gold standard imaging examination for the evaluation of degenerative changes in the spine, ${ }^{7}$ the radiographic examination allows the identification of findings associated with spondylosis, including osteophytosis, loss of disc height, sclerosis, and subchondral cysts in the vertebral plateaus. ${ }^{8}$ Recently, a severity scale for degenerative lumbar disease (DLD) that considers a total spine radiographic examination and assesses the presence of radiographic signs of spondylosis, its extension throughout the lumbar segments, and the presence of signs of instability, such as spondylolisthesis or laterolisthesis, was presented. ${ }^{1}$ The objectives of the present study were to evaluate the impact of the severity of DLD on the occurrence of spinal deformity and on the choice of treatment, whether conservative or surgical.

\section{METHODS}

\section{Type of study and ethical aspects}

This is a cross-sectional study considering a cohort of prospectively selected patients in outpatient care at a clinic specializing in spinal surgery. The study was approved by the Institutional Review Board of the service where it was conducted (CAAE: 18013219.7.0000.5463) and considered a bank of radiographic images of patients who signed the informed consent form regarding the storage of their examinations. Information from the medical records was also considered, including demographic data and choice of treatment, whether conservative or surgical.

\section{Study population}

Adult individuals ( $\geq 18$ years of age) complaining of chronic low back pain (starting at least 3 months before), with or without associated symptoms of radiculopathy were included. The exclusion criteria were previous neurological or spinal surgery, neurological or neuromuscular diseases, history of spinal trauma or neoplastic spinal disease, complaints of hip/knee/ankle/foot disability that can alter joint positioning, inadequate radiography not permitting visualization from $\mathrm{C} 2$ to the head of the femur or without sufficient resolution to analyze the radiographic signs of DLD.

\section{Grading of degenerative lumbar disease}

Total spine radiographs (panoramic) in frontal and lateral views, considering the lumbar segment, were used to conduct the analysis. All the examinations were performed at the same radiology service following a standardized technique: comfortable standing posture with shoulders at $45^{\circ}$ elevation and elbows flexed, resting the fingertips on the clavicles or on the face. ${ }^{9}$ As all the images were digitalized in DICOM format, it was possible to enlarge them while maintaining the quality and resolution necessary for accurate assessment level by level of the entire lumbar segment. According to the radiographic findings of DLD, the patients were graded as follows. (Figure 1)

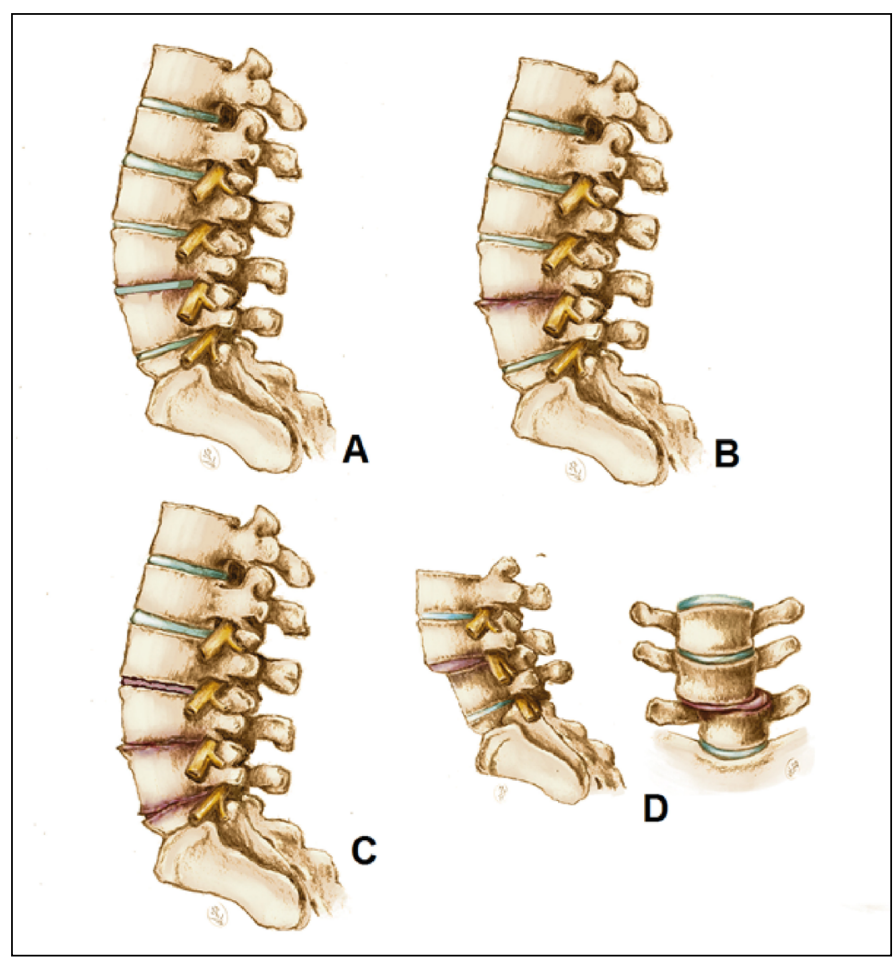

Figure 1. Illustration of the DLD radiographic grading scale. A. Grade 0, B. Grade I, C. Grade II, D. Grade III.

- Grade 0: absence of signs of degenerative disease in the lumbar spine.

- Grade I: presence of signs of degenerative disease in one or two lumbar spinal segments, without scoliosis or signs of instability.

- Grade II: presence of signs of degenerative disease in three or more segments of the lumbar spine, without signs of scoliosis or instability.

- Grade III: presence of signs of degenerative disease in the lumbar spine associated with scoliosis (coronal inclination measured using the Cobb technique greater than or equal to $30^{\circ}$ ) and/or signs of instability, such as laterolisthesis (>2 mm) and spondylolisthesis (at least grade 2).

\section{Diagnosis of adult spinal deformity (ASD)}

The same total spine radiographs used to grade DLD were used to diagnose ASD. For this, the presence of coronal plane deformity (scoliosis) and loss of spinopelvic sagittal alignment were evaluated. The radiographic parameters were measured using Surgimap Spine software (Nemaris Inc. New York, USA), a tool validated for radiographic evaluation of the spine. ${ }^{10}$ The parameters described by the International Spine Study Group were considered as the criteria for the ASD diagnosis: presence of scoliosis (coronal Cobb angle $\geq 20^{\circ}$ ), thoracic kyphosis (T4-T12 $\geq 60^{\circ}$, pelvic version $(P V) \geq 20^{\circ}$, sagittal vertical axis $(S V A)>5$ $\mathrm{cm}$, and the discrepancy between pelvic incidence and lumbar lordosis $(\mathrm{PI}-\mathrm{LL})>10^{\circ} .{ }^{5}$ The presence of at least one of these criteria defined an ASD diagnosis.

\section{Statistical analysis}

Statistical analysis was conducted using the R program, version 3.4.9 (R Foundation for Statistical Computing, Vienna, Austria). The comparison of the occurrence of ASD among the different grades of the DLD severity scale was analyzed using the Chi-squared test and the odds ratio (OR) was also calculated for each DLD grade, with a confidence interval of $95 \%(95 \% \mathrm{Cl})$. The type of treatment choice, between conservative and surgical, was compared among the DLD severity scale grades using Fisher's exact test. The level of significance considered for all statistical analysis was $5 \%$. 


\section{RESULTS}

\section{Study population}

One hundred and thirty patients, 97 of whom were women (75\%), were included and the mean age was 57 years (SD: 14.6), ranging from 18 to 95 years. Regarding the DLD grading scale, $12(9 \%)$ patients were grade 0,41 (32\%) grade I, 43 (33\%) grade II, and 34 (26\%) grade IV. Considering the radiographic parameters described, $40(31 \%)$ patients were diagnosed with ASD. Out of the total sample, only $10(8 \%)$ patients opted for surgical treatment.

\section{Correlation between DLD severity and ASD occurrence}

The more advanced the DLD grade, the greater the rate of ASD occurrence among the patients. No grade 0 patients were diagnosed with ASD, while the diagnosis occurred in $24 \%$ of grade I patients, $35 \%$ of grade II patients, and $44 \%$ of grade III patients (Figure 2, Table 1), with a statistically significant difference $(P=0.02)$. Patients classified as grade III on the DLD grading scale had higher odds of having an ASD diagnosis $(O R=2.22, P<0.05$, $95 \% \mathrm{Cl}=0.90-5.45)$ than the other DLD grades

\section{Correlation between DLD severity and choice of treatment}

Of the total patient sample, $7.7 \%$ opted for surgical treatment. According to the DLD grading scale, the percentage of patients who opted for surgical treatment varied, corresponding to $9 \%$ of grade 0 patients, $2.5 \%$ of grade I patients, $7.5 \%$ of grade II patients, and $17 \%$ of grade III patients (Figure 3, Table 2), but without any statistically significant difference $(P=0.239)$.

\section{DISCUSSION}

Recently, a DLD grading scale based on the analysis of radiographic images of the total spine (panoramic) was presented. ${ }^{1}$ This scale demonstrated high reproducibility and proved to be easily applicable. ${ }^{1}$ The present study sought to evaluate whether such a DLD grading scale might influence certain clinical aspects of the patients, including the diagnosis of ASD and the type of treatment option, whether conservative or surgical.

ASD consists of a wide variety of clinical presentations (neglected idiopathic scoliosis, degenerative lumbar scoliosis, loss of sagittal alignment, etc.) and, therefore, its real prevalence is difficult to assess precisely, although it is believed that it is trending to increase along with the aging of the global population. ${ }^{4,5}$ While Schwab et al. reported that up to $60 \%$ of the individuals above 60 years of age present ASD, using the presence of coronal curves with an angle of magnitude $>10^{\circ}$ as a diagnostic

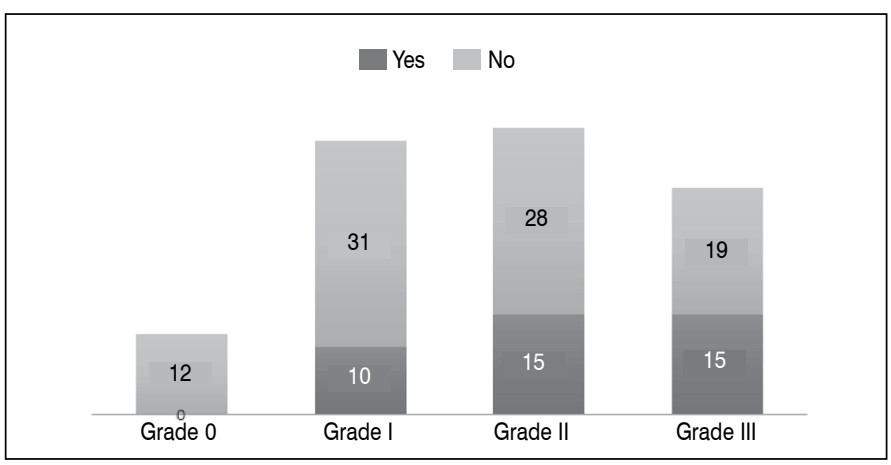

Figure 2. Rate of occurrence of adult spinal deformity by degenerative lumbar disease grade.

Table 1. Occurrence of adult spinal deformity by degenerative lumbar disease scale grade.

\begin{tabular}{c|c|c|c|c|c}
\hline ASD & Grade 0 & Grade I & Grade II & Grade III & \multirow{2}{*}{ P $^{*}$} \\
\cline { 1 - 5 } Yes & 0 & $10(24 \%)$ & $15(35 \%)$ & $15(44 \%)$ & \multirow{2}{*}{0.02} \\
\cline { 1 - 5 } No & $12(100 \%)$ & $31(76 \%)$ & $28(65 \%)$ & $19(56 \%)$ & \\
\hline
\end{tabular}

ASD: adult spinal deformity. ${ }^{*}$ Chi-squared.

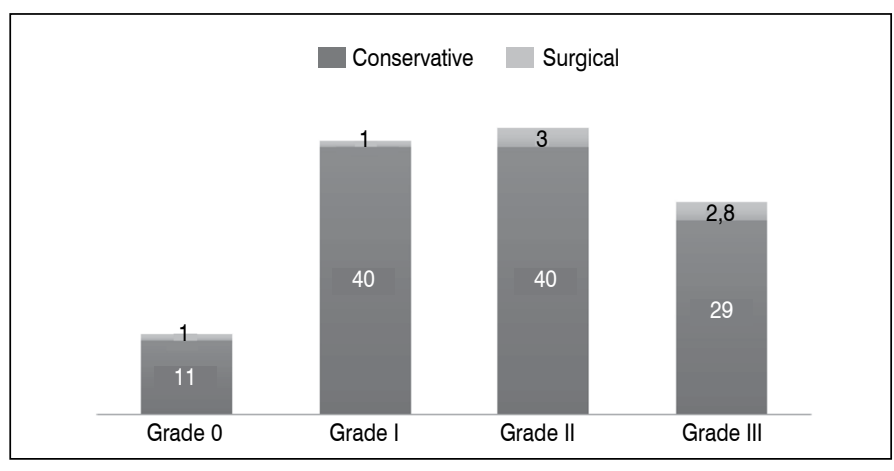

Figure 3. Type of treatment by degenerative lumbar disease grade.

Table 2. Type of treatment by degenerative lumbar disease scale grade.

\begin{tabular}{c|c|c|c|c|c}
\hline Treatment option & Grade 0 & Grade I & Grade II & Grade III & P* $^{*}$ \\
\cline { 1 - 5 } Conservative & $11(91 \%)$ & $40(97.5 \%)$ & $40(92.5 \%)$ & $29(83 \%)$ & \multirow{2}{*}{0.239} \\
\cline { 1 - 5 } Surgical & $1(9 \%)$ & $1(2.5 \%)$ & $3(7.5 \%)$ & $5(17 \%)$ & \\
\hline
\end{tabular}

*Fisher's exact test.

criterion, ${ }^{11}$ a recent Brazilian study found an occurrence rate of $18 \%$ of the population diagnosed with $\mathrm{ASD}$ and also demonstrated a relationship with increasing age, with $29 \%$ of the individuals aged $\geq 60$ years. ${ }^{12}$

In the present study, which considered only patients of a spinal service with complaints of low back pain and/or lumbosciatalgia, the ASD occurrence rate was $30 \%$ for the total sample. The radiographic parameters consider for an ASD diagnosis were those recommended by the International Spine Study Group ${ }^{5}$ studies, which were also adopted by the study published by Barreto et al. ${ }^{12}$ What was new was that the present study demonstrated that, according to the scale proposed by Vasconcelos et al., ${ }^{1}$ the more frequent the ASD diagnosis the more advanced the DLD grade. ${ }^{1}$ Moreover, the simple fact that the patients had a more advanced grade of DLD (grade III), made their chances of being diagnosed with ASD 2 times greater than patients with the other grades of DLD.

Although a good number of the patients diagnosed with ASD have minor complaints, or are asymptomatic, a portion of these patients present varying pain and functional disability profiles and require more aggressive treatment, including surgery. ${ }^{13,14}$ Other studies have shown that patients diagnosed with ASD associated with loss of sagittal alignment have worse quality of life indicators and even greater predominance in the choice of surgical treatment. ${ }^{2-4,15}$ Although the DLD grading system used in the present study has been shown to be correlated with the ASD diagnosis, there was no correlation between the different DLD grades and the determination of the type of patient treatment, between conservative or surgical.

Considering DLD alone, low back pain symptoms accompanied or not by radiation to a lower limb have an extremely high prognosis for improvement with conservative treatment. ${ }^{9,16-19}$ Thus, in general, in most cases conservative treatment is chosen with surgery limited to a small group of patients. ${ }^{16,19}$ Similar information was also observed in the present study, with only $7.7 \%$ of patients choosing surgical treatment. The fact that there was no difference in the rate of choice of surgical treatment according to the DLD scale grade suggests that there was no correlation between the radiographic findings and the choice of treatment. It is known that the main factor associated with the choice of surgical treatment is the intensity of symptoms associated with functional limitation, ${ }^{17,20}$ as well as the persistence of the symptoms, ${ }^{17,21}$ rather than the radiological pattern of the disease.

The main limitation of the study is its retrospective nature, which makes impossible a progressive evaluation of the patients' treatments according to the DLD scale grade, as well as according to a diagnosis or not of ASD. Another important limitation is the lack of analysis of the quality of life indicators and their correlation with the variables considered. However, the results found in the present study, in which there was a correlation between the DLD scale grade and the occurrence of ASD, motivates new preferably prospective studies to analyze the impact of these variables on quality of life indicators. 


\section{CONCLUSIONS}

The DLD grading scale was correlated to the occurrence of ASD and, when comparing the scale grade and the odds of diagnosis, the deformity diagnosis rate was more than double in the most advanced grade of DLD than in the other grades. The treatment of choice was conservative in a very small number of patients analyzed and there was no difference in the rate of patient surgeries according to the DLD grading scale.

All authors declare no potential conflict of interest related to this article.

CONTRIBUTION OF THE AUTHORS: Each author made significant individual contributions to this manuscript. Study concept and design: RRP. Data acquisition and Institutional Review Board approval: RB. Data collection: RB. Data analysis and interpretation: RRP. Development of the article: RRP. Review of the final version for submission: RRP, RB, and CEASO

\section{REFERENCES}

1. Vasconcelos IT, Sant'Anna DA, Oliveira CEAS, Herrero CFPS, Pratali RR. Escala de graduação da doença degenerativa lombar em exames de radiografia panorâmica da coluna vertebral. Coluna/Columna. 2019;18(1)32-6.

2. Glassman SD, Bridwell K, Dimar JR, Horton W, Berven S, Schwab F. The impact of positive sagittal balance in adult spinal deformity. Spine (Phila Pa 1976). 2005;30(18):2024-9.

3. 3. Lafage V, Schwab F, Patel A, Hawkinson N, Farcy JP. Pelvic tilt and truncal inclination: two key radiographic parameters in the setting of adults with spinal deformity. Spine (Phila Pa 1976). 2009:34(17):E599-606.

4. Schwab FJ, Blondel B, Bess S, Hostin R, Shaffrey Cl, Smith JS, et al. Radiographical spinopelvic parameters and disability in the setting of adult spinal deformity: a prospective multicenter analysis. Spine (Phila Pa 1976). 2013;38(13):E803-12.

5. Schwab F, Ungar B, Blondel B, Buchowski J, Coe J, Deinlein D, et al. SRS-Schwab Adult Spinal Deformity Classification: A Validation Study. Spine (Phila Pa 1976). 2012;37(12):1077-82.

6. Fu KMG, Rhagavan P, Shaffrey $\mathrm{Cl}$, Shernavvsky DR, Smith JS. Prevalence, severity and impact of foraminal and canal stenosis among adults with degenerative scoliosis. Neurosurgery. 2011;69(6):1181-7.

7. Pfirrmann CW, Metzdorf A, Zanetti M, Hodler J, Boos N. Magnetic resonance classification of lumbar intervertebral disc degeneration. Spine (Phila Pa 1976). 2001:26(17):1873-8.

8. Andersson GBJ, Biyani A, Ericksen ST. Lumbar disc disease. In: Herkowitz HN, Garfin SR, Eismont FJ, Bell GR, Balderston RA, editors. Rothman-Simeone The Spine 6th Edition. Philadelphia: Elsevier \& Saunders: 2011: 846-86.

9. Andersson GB. Epidemiological features of chronic low-back pain. Lancet. 1999;354(9178):581-5

10. Lafage R, Ferrero E, Henry JK, Challier V, Diebo B, Liabaud B, et al. Validation of a new computer-assisted tool to measure spino-pelvic parameters. Spine J. 2015;15(12):2493-502.

11. Schwab F, Dubey A, Gamez L, El Fegoun AB, Hwang K, Pagala M, et al. Adult scoliosis: prevalence, SF-36, and nutritional parameters in an elderly volunteer population. Spine (Phila Pa 1976). 2005;30(9):1082-5

12. Barreto MVA, Pratali RR, Barsotti CEG, Santos FPE, Oliveira CEAS, Nogueira MP. Incidência da deformidade vertebral no adulto e sua distribuição quanto à classificação SRS-Schwab. Coluna/Columna. 2015;14(2):93-6.
13. Smith JS, Fu KM, Urban P. Shaffrey C. Neurological symptoms and deficits in adults with scoliosis who present to a surgical clinic: incidence and association with the choice of operative versus nonoperative management. J Neurosurg Spine. 2008;9(4):326-31.

14. Smith JS, Shaffrey Cl, Berven S, Glassman S, Hamill C, Horton W, et al. Operative versus nonoperative treatment of leg pain in adults with scoliosis: a retrospective review of a prospective multicenter database with two-year follow-up. Spine (Phila Pa 1976). 2009;34(16):1693-8.

15. Terran J, Schwab F, Shaffrey Cl, Smith JS, Devos P, Ames CP, et al. The SRS-Schwab adult spinal deformity classification: assessment and clinical correlations based on a prospective operative and nonoperative cohort. Neurosurgery. 2013;73(4):559-68.

16. Taylor VM, Deyo RA, Cherkin DC, Kreuter W. Low back pain hospitalization. Recent United States trends and regional variations. Spine (Phila Pa 1976). 1994;19(11):1207-12.

17. Weinstein JN, Tosteson TD, Lurie JD, Tosteson AN, Hanscom B, Skinner JS, et al. Surgical vs nonoperative treatment for lumbar disk herniation: the Spine Patient Outcomes Research Trial (SPORT): a randomized trial. JAMA. 2006;296(20):2441-50.

18. Atlas SJ, Deyo RA, Keller RB, Chapin AM, Patrick DL, Long JM, et al. The Maine Lumbar Spine Study, Part II. 1-year outcomes of surgical and nonsurgical management of sciatica. Spine (Phila Pa 1976). 1996;21(15):1777-86.

19. Brox JI, Nygaard ØP, Holm I, Keller A, Ingebrigtsen T, Reikerås O. Four-year follow-up of surgical versus non-surgical therapy for chronic low back pain. Ann Rheum Dis. 2010;69(9):1643-8.

20. Neuman BJ, Baldus C, RN, Zebala LP, Kelly MP, Shaffrey C, Edwards C 2nd, et al. Patient factors that influence decision making: randomization versus observational nonoperative versus observational operative treatment for Adult Symptomatic Lumbar Scoliosis (ASLS). Spine (Phila Pa 1976). 2016:41(6):E349-58.

21. Weinstein JN, Lurie JD, Tosteson TD, Zhao W, Blood EA, Tosteson ANA, et al. Surgical compared with nonoperative treatment for lumbar degenerative spondylolisthesis. J Bone Joint Surg Am. 2009;91(6):1295-304. 